\title{
Relationship between Physical Activities, Stress and Eating Patterns with the Risk of Hipertension in Women in Baiturrahman Community Health Centers Banda Aceh
}

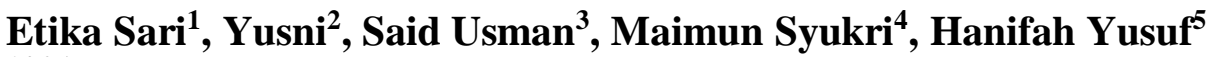 \\ 1,2,3,4,5 Magister Program in Public Health, Faculty of Medicine, Universitas Syiah Kuala, Indonesia \\ etikasarifkm95@gmail.com,yusni@unsyiah.ac.id,saidusman@unsyiah.ac.id,maimun_62@yahoo.com, \\ hans_yusuf1104@yahoo.com
}

\begin{abstract}
The pattern of disease events at this time has experienced a change marked by changes in disease and death that were originally dominated by infectious diseases switch to non-communicable diseases. In the 2018 Riskesdas results the prevalence of hypertension in Aceh increased compared to 2013. Purpose: to find out the factors associated with the incidence of hypertension in women at the Baiturrahman Health Center in Banda Aceh City. Research Methods: This research is a type of quantitative research with cross-sectional study design conducted on 124 samples. Sampling was carried out using the Accidental Sampling technique. Data analysis uses univariate, bivariate and multivariate. Statistical analysis using chi-square and logistic regression. Results: The results showed that there was a significant relationship between family history ( $p$-value $=0.007, O R=2.8$ ), food consumption patterns ( $p$-value $=0.025$, OR $=2.5$ ), obesity status ( $p$-value $=0.046$, OR $=2.2)$, Physical activity ( $p$-value $=$ $0.012, O R=3.2)$ and Stress ( $p$-value $=0.017, O R=2.9)$ with the incidence of hypertension in women. Multivariate analysis results indicate that family history is a dominant factor in the incidence of hypertension $(O R=4.7)$. Conclusion: Family history, food consumption patterns, obesity, physical activity and stress are related to the incidence of hypertension and the most dominant factor in the incidence of hypertension in women in the working area of the Baiturrahman Health Center in Banda City is family history of hypertension.
\end{abstract}

Keywords

hypertension; family history, food consumption patterns, obesity, physical activity and stress

\section{Introduction}

The pattern of disease events at this time has experienced a change marked by changes in disease and death which were originally dominated by infectious diseases switch to noncommunicable diseases (Purnamasari, 2019). Non-communicable diseases (PTM), also known as chronic diseases, tend to last long and are the result of a combination of genetic, physiological, environmental and behavioral factors (WHO, 2018). Non-communicable diseases (PTM) kill 41 million people each year or $71 \%$ of all deaths globally influenced by lifestyle such as unhealthy diets, inadequate physical activity, exposure to tobacco smoke or dangerous alcohol use (WHO, 2018). The results of Riskesdas in 2018 showed an increase in PTM in Indonesia such as diabetes mellitus, hypertension and obesity (Kemenkes RI, 2018).

Health is a very important element of the quality of life in national development. The national health system has established that the goal of health development is to increase awareness, willingness, and ability to live healthy for everyone so that a high degree of public 
health can be realized - high human resources, as an investment for socially and economically productive development. (Hasibuan, 2020).

An unhealthy lifestyle can increase blood pressure, overweight, hyperglycemia (high blood glucose levels) and hyperlipidemia (high blood fat levels) which are metabolic risk factors that can cause cardiovascular disease (WHO, 2018). Changes in lifestyle that are increasingly modern at this time cause an increasing number of PTM events such as hypertension (WHO, 2018). Hypertension is a condition of an increase in blood pressure higher than 140/90 millimeters of mercury (mmHG) (WHO, 2019). The number $140 \mathrm{mmHG}$ refers to systolic and the number $90 \mathrm{mmHG}$ refers to diastolic. Systolic pressure is the pressure when the heart pumps blood throughout the body and diastolic blood pressure is the pressure when the heart muscle relaxes, before returning to pump blood (WHO, 2019).

Current trends show that the number of adults with hypertension is increasing, with an increase seen mainly in low and middle income countries and it is estimated that by 2025 hypertension will increase to 1.56 billion in adults (Tabrizi et al., 2016). According to the results of the Basic Health Research (Riskesdas) in 2007, 2013 and 2018 aimed at increasing the prevalence of PTM such as hypertension, nationally the results of the 2018 Riskesdas showed that the prevalence of people with high blood pressure was $34.1 \%$.

Based on the 2018 Riskesdas data, cases of hypertension in Aceh province experienced fluetime, in the results of Riskesdas in 2013 the prevalence of hypertension in Aceh decreased compared to 2007, but in the results of riskesdas in 2018 the prevalence of hypertension in Aceh increased again. Hyperteni prevalence data obtained by researchers from the Banda Aceh City Health Office, showed that during the last 3 years, the highest hypertension cases were in the Baiturrahman Health Center in Banda Aceh City. Based on several things that have been stated previously, the researcher wants to conduct research on the determinants of hypertension in the working area of the Baiturrahman puskesmas.

\section{Research Method}

This research is a type of quantitative research with a Crossectional Study design. The sample in this study was 124 people, carried out matching (matching) based on age and gender. Sampling was carried out using the Accidental Sampling technique at the Baiturrahman Health Center, Banda Aceh City. Data collection was carried out using a standard questionnaire. Hypertension is a dependent variable, while family history, food consumption patterns, obesity, physical activity, and stress are the independent variables studied. The statistical analysis conducted in this study was the Chi-Square test and multiple logistic regression analysis using SPSS IBM 25 software, with a significance level of $p$ $<0.05$. This study has received permission from the Health Research Ethics Commission of the Faculty of Medicine at Syiah Kuala University / Regional General Hospital Dr. Zainoel Abidin Banda Aceh with registration number 072 / EA / FK-RSUDZA / 2020.

\section{Discussion}

The number of respondents in this study was 124 , all respondents were women aged 25-55 years. Of the 124 respondents, $51.6 \%$ had a family history of hypertension, $63.7 \%$ often consumed foods that trigger hypertension. $56.5 \%$ were obese, $53.2 \%$ had moderate physical activity, and $52.4 \%$ had moderate stress levels (table 1). 
Table 1. Description of the Independent Variables

\begin{tabular}{lcc}
\hline \multicolumn{1}{c}{ Variable } & $\mathrm{n}$ & $\%$ \\
\hline Family history of hypertension & & \\
Yes & 64 & 51,6 \\
No & 60 & 48,4 \\
\hline Food consumption patterns & & \\
Often & 79 & 63,7 \\
Not often & 45 & 36,3 \\
\hline Obesity & \multicolumn{2}{c}{} \\
Yes & 70 & 56,5 \\
No & 54 & 43,5 \\
\hline Physical activity & \multicolumn{2}{c}{} \\
Light & 37 & 29,8 \\
Medium & 66 & 53,3 \\
Heavy & 21 & 16,9 \\
\hline Stress level & \multicolumn{2}{c}{} \\
Heavy & 39 & 31,5 \\
Medium & 65 & 52,4 \\
Light & 20 & 16,1 \\
\hline
\end{tabular}

The results of the multiple logistic regression analysis showed that family history, stress, obesity, and food consumption patterns had a significant relationship with the incidence of hypertension (table 3). Family history is the most dominant risk factor for hypertension, with $\mathrm{OR}=4.7$. Negelkerke R Square value obtained from this analysis is 0.382 . This value indicates that family history, stress level, obesity, and consumption of foods that trigger hypertension contribute $38.2 \%$ to the incidence of hypertension, while the rest is determined by other variables outside this study.

Table 2. Logistic Regression Test Results

\begin{tabular}{lcccc}
\hline \multirow{2}{*}{ Variable Name } & \multirow{2}{*}{ P-Value } & OR & \multicolumn{2}{c}{ CI 95,0\% } \\
Family history & 0.001 & 4.772 & 1.864 & 12.215 \\
Stress & 0.032 & 4.204 & 4.204 & 1.133 \\
Obesity & 0.035 & 2.630 & 1.071 & 6.456 \\
Food & 0,039 & 2.755 & 1.050 & 7.227 \\
consumption & & & & \\
patterns & & & & \\
\hline
\end{tabular}

Genetic factors are one of the important factors that influence essential hypertension (Peng et al., 2020). Essential hypertension is a multifactorial disease caused by genetic and environmental factors (Peng et al., 2020 and Staessen et al., 2003), this is consistent with the results of research showing that there are two main factors that influence the incidence of hypertension, namely genetic factors and factors environment (Aune et al., 2016). The results showed that the influence of genetic factors on hypertension was around 20-55\% (Fang et al., 2019 and Levy et al., 2009). 
Based on the results of research conducted in Japan, consumption of foods high in sodium can cause hypertension by 1.2 times in those with higher sodium intake compared with lower (Takase et al., 2015). The effect of high sodium intake on the onset of hypertension occurs through an increase in plasma volume, cardiac output, and blood pressure (Shils and Shike, 2006). Excess intake of sodium will increase fluid from cells, where water will move towards an electrolyte solution that has a higher concentration, this result in an increase in blood plasma volume and will increase cardiac output, so that blood pressure increases (Muliyati et al., 2011). In addition, high sodium intake can reduce the diameter of the arteries, so that the heart pumps harder to push the increased blood volume through narrow spaces (Shils and Shike, 2006a).

The results of research conducted by Cahyahati (2018) on 100 elderly coastal areas showed there was a relationship between sodium intake with systolic and diastolic blood pressure. The most source of sodium consumed by respondents came from table salt and sea preparations (anchovies, salted fish and shellfish). The results of this study are in line with the results of research from Astuti (2017) which states that there is a very significant relationship $(0,000)$ in the consumption patterns of hypertension-triggering foods with hypertension events such as high cholesterol, milk and processed foods, as well as foods with high MSG content. Epidemiological studies have shown that people with high sodium intake are more likely to have hypertension compared to those with relatively low sodium consumption (Pressure, 1988; Mente et al., 2014). Although excessive sodium intake causes an increase in blood pressure, high sodium intake does not in fact cause hypertension in all people because the sensitivity of individuals to sodium intake is influenced by genetics (Luft et al., 1979; Murray et al., 1978). Another study conducted by Feryadi (2012) also showed that respondents with the consumption of fatty foods in the moderate category mostly did not experience hypertension $(68.57 \%)$ and respondents with the consumption of fatty foods in the category often often experienced hypertension (84.21\%). this shows the more frequent consumption of fatty foods the more risk of hypertension (Feryadi et al., 2014).

Based on the results of research conducted by Lestari (2010), it is known that subjects who are included in the IMT category $>25 \mathrm{~kg} / \mathrm{m} 2$ have a 1.8 times risk of suffering from hypertension compared to subjects who are included in the IMT category $<25 \mathrm{~kg} / \mathrm{m} 2$. Physiological changes in the body that can occur due to obesity include an increase in the amount of free fatty acids that will narrow blood vessels and an increase in blood volume which causes the heart to work harder to pump blood throughout the body so that blood pressure will increase. In addition, an increase in the sympathetic nervous system, insulin resistance, and increased activity of the angiostensin aldosterone renin system (Shils and Shike, 2006b). Study of Trials of Hypertension Prevention Phase II, shows that weight loss is associated with a decrease in blood pressure and a reduced risk of developing hypertension (Neter et al., 2003).

The results of this study indicate that there is a significant relationship between the level of physical activity and the incidence of hypertension with $\mathrm{OR}=3.2$ times more risk in people with mild physical activity. The results of this study are in line with research conducted by Lestari (2010) which shows that there is a significant relationship between physical activity and the incidence of hypertension in women aged 30-40 years. Increased physical activity can reduce the risk of hypertension. This research is in accordance with the results of a meta-analysis study which states that high physical activity can reduce systolic and diastolic blood pressure by $3 \mathrm{mmHg}$ (Kelley and Kelley, 2000).

Stress can trigger the occurrence of hypertension which is thought to be a relationship through increased sympathetic nerve activity so as to raise blood pressure intermittently or erratically (Martono, 2015). Excessive stress can trigger the onset of increased adrenaline 
horomon so that the heart pumps blood faster and increases (Sukma et al., 2019). Some risk factors that might explain gender differences in stress prevalence include differences in sex hormones, differences in dealing with problems, differences in socialization, differences in frequency and reactions to stress in life, differences in social roles and cultural influences (Sudawam and Livana, 2017). The results of this study indicate that the stress level is related to hypertension, the lower the stress level of the respondent, the lower the prevalence of prehypertension and hypertension. The results of this study are in line with the research of $\mathrm{Hu}$ et al., (2015) and Agustina and Raharjo (2015) where stress is significantly related to hypertension. Research Liu et al., (2017) also states that psychosocial stress is associated with an increased risk of hypertension.

\section{Conclusion}

The results showed that there was a significant relationship between family history ( $\mathrm{p}$ value $=0.007, \mathrm{OR}=2.8)$, food consumption patterns $(\mathrm{p}$-value $=0.025, \mathrm{OR}=2.5)$, obesity status $(\mathrm{p}$-value $=0.046, \mathrm{OR}=2.2)$, Physical activity $(\mathrm{p}$-value $=0.012, \mathrm{OR}=3.2)$ and Stress $(\mathrm{p}$-value $=0.017, \mathrm{OR}=2.9)$ with the incidence of hypertension in women. Multivariate analysis results indicate that family history is a dominant factor in the incidence of hypertension $(\mathrm{OR}=4.7)$. Family history, food consumption patterns, obesity, physical activity and stress are related to the incidence of hypertension and the most dominant factor in the incidence of hypertension in women in the working area of the Baiturrahman Health Center in Banda City is a family history of hypertension.

\section{References}

Agustina, R., Raharjo, B.B. (2015). Faktor Risiko Yang Berhubungan Dengan Kejadian Hipertensi Usia Produktif (25-54 Tahun). Unnes Journal of Public Health 4.

Astuti, I.S.W. (2017). Analisis Korelasi Pola Konsumsi Makanan Pemicu Hipertensi Pada Petani Di Pedesaan Kabupaten Jember. Journal of Agromedicine and Medical Sciences Vol. 3 No.3.

Aune, D., Sen, A., Norat, T., Janszky, I., Romundstad, P., Tonstad, S., Vatten, L.J. (2016). Body mass index, abdominal fatness, and heart failure incidence and mortality: a systematic review and dose-response meta-analysis of prospective studies. Circulation 133, 639-649.

Cahyahati, J.S., Kartini, A., Rahfiludin, M.Z.(2018). Hubungan Asupan Makanan (Lemak, Natrium, Magnesium) Dan Gaya Hidup Dengan Tekanan Darah Pada Lansia Daerah Pesisir (Studi Di Wilayah Kerja Puskesmas Tegal Barat Kota Tegal). Jurnal Kesehatan Masyarakat (e-Journal) Volume 6, Nomor 5.

Fang, X., Zhang, Y., Peng, Q., Yin, X.(2019). Familial aggregation and heritability of hypertension in Han population in Shanghai China: a case-control study. Clinical hypertension $25,17$.

Feryadi, R., Sulastri, D., Kadri, H.(2014). Hubungan kadar profil lipid dengan kejadian hipertensi pada masyarakat etnik Minangkabau di kota Padang tahun 2012. Jurnal Kesehatan Andalas 3.

Hasibuan, S. M. et al. (2020). Relationship of Family Income and Family Support with Maternal Reference in Pregnant Women in Pantai Cermin BEmONC, Langkat District, 2019. Budapest International Research and Critics Institute-Journal (BIRCI-Journal). p. 486-493. 
Hu, B., Liu, X., Yin, S., Fan, H., Feng, F., Yuan, J.(2015). Effects of psychological stress on hypertension in middle-aged Chinese: a cross-sectional study. PLoS One 10.

Kelley, G.A., Kelley, K.S. (2000). Progressive resistance exercise and resting blood pressure: a meta-analysis of randomized controlled trials. Hypertension 35, 838-843.

Kemenkes RI. (2018). Hasil Utama Riskesdas 2018. Kementerian Kesehatan RI, Jakarta.

Levy, D., Ehret, G.B., Rice, K., Verwoert, G.C., Launer, L.J., Dehghan, A., Glazer, N.L., Morrison, A.C., Johnson, A.D., Aspelund, T. (2009). Genome-wide association study of blood pressure and hypertension. Nature genetics 41, 677 .

Liu, M.-Y., Li, N., Li, W.A., Khan, H. (2017). Association between psychosocial stress and hypertension: a systematic review and meta-analysis. Neurological research 39, 573580.

Luft, F.C., Rankin, L.I., Bloch, R., Weyman, A.E., Willis, L.R., Murray, R.H., Grim, C.E., Weinberger, M.H. (1979). Cardiovascular and humoral responses to extremes of sodium intake in normal black and white men. Circulation 60, 697-706.

Martono, N. (2015). Karakteristik Kebiasaan Merokok Pada Pasien Laki-Laki Penderita Hipertensi Di Rumah Sakit Islam Klaten. Cerata Jurnal Ilmu Farmasi 1.

Mente, A., O’Donnell, M.J., Rangarajan, S., McQueen, M.J., Poirier, P., Wielgosz, A., Morrison, H., Li, W., Wang, X., Di, C. (2014). Association of urinary sodium and potassium excretion with blood pressure. New england journal of medicine 371, 601611.

Muliyati, H., Syam, A., Sirajuddin, S. (2011). Hubungan pola konsumsi natrium dan kalium serta aktifitas fisik dengan kejadian hipertensi pada pasien rawat jalan di RSUP dr. Wahidin Sudirohusodo Makassar. Media Gizi Masyarakat Indonesia 1, 46-51.

Murray, R.H., Luft, F.C., Bloch, R., Weyman, A.E.(1978). Blood pressure responses to extremes of sodium intake in normal man. Proceedings of the Society for Experimental Biology and Medicine 159, 432-436.

Neter, J.E., Stam, B.E., Kok, F.J., Grobbee, D.E., Geleijnse, J.M. (2003). Influence of weight reduction on blood pressure: a meta-analysis of randomized controlled trials. Hypertension 42, 878-884.

Peng, Q., Shao, Y.Q., Zhang, Y.Y., Xiang, F. (2020). Association between family history and essential hypertension in Han population in Shanghai China. Europe PMC. https://doi.org/10.21203/rs.2.11431/v2

Pressure, I.A.I.S. of E.E. and B.(1988). Results for 24 hour urinary sodium and potassium excretion. Intersalt Cooperative Research Group. Bmj 297, 319-328.

Purnamasari, D.(2019). The Emergence of Non-communicable Disease in Indonesia. Acta Medica Indonesiana 50, 273.

Shils, M.E., Shike, M., 2006a. Modern Nutrition in Health and Disease. Lippincott Williams \& Wilkins.

Shils, M.E., Shike, M. (2006b.) Modern Nutrition in Health and Disease. Lippincott Williams \& Wilkins.

Staessen, J.A., Wang, J., Bianchi, G., Birkenhäger, W.H., 2003. Essential hypertension. The Lancet 361, 1629-1641. https://doi.org/10.1016/S0140-6736(03)13302-8

Sudawam, S., Livana, P.H. (2017). Gambaran Tingkat Stres Lansia Dengan Hipertensi. Jurnal Ilmiah Permas: Jurnal Ilmiah STIKES Kendal 7, 32-36.

Sukma, E.P., Yuliawati, S., Hestiningsih, R., Ginandjar, P. (2019). Hubungan Konsumsi Alkohol, Kebiasaan Merokok, Dan Tingkat Stres Dengan Kejadian Hipertensi Usia Produktif (Studi Di Wilayah Kerja Puskesmas Ngemplak Simongan Semarang). Jurnal Kesehatan Masyarakat (e-Journal) 7, 122-128. 
Tabrizi, J.S., Sadeghi-Bazargani, H., Farahbakhsh, M., Nikniaz, L., Nikniaz, Z. (2016). Prevalence and Associated Factors of Prehypertension and Hypertension in Iranian Population: The Lifestyle Promotion Project (LPP). PLOS ONE 11, e0165264. https://doi.org/10.1371/journal.pone.0165264

Takase, H., Sugiura, T., Kimura, G., Ohte, N., Dohi, Y. (2015). Dietary sodium consumption predicts future blood pressure and incident hypertension in the Japanese normotensive general population. Journal of the American Heart Association 4, e001959.

WHO. (2019). Hypertension [WWW Document]. URL https://www.who.int/news-room/factsheets/detail/hypertension (accessed 4.3.20).

WHO. (2018). Non communicable diseases [WWW Document]. URL https://www.who.int/news-room/fact-sheets/detail/noncommunicable-diseases (accessed 11.28.19). 